NBER WORKING PAPER SERIES

\title{
STRUCTURAL ESTIMATION OF CALORIC INTAKE, EXERCISE, SMOKING, AND OBESITY
}

\author{
Inas Rashad \\ Working Paper 11957 \\ http://www.nber.org/papers/w11957 \\ NATIONAL BUREAU OF ECONOMIC RESEARCH \\ 1050 Massachusetts Avenue \\ Cambridge, MA 02138 \\ January 2006
}

Research for this paper was supported by grant number 1R01 DK54826 from the National Institute of Diabetes and Digestive and Kidney Diseases to the National Bureau of Economic Research. The author wishes to thank Michael Grossman, Shin-Yi Chou, Robert Kaestner, John Cawley, Gregory Colman, Mindy Marks, and Roger Tutterow for comments on earlier versions of the paper. This paper has not undergone the review accorded official NBER publications; in particular, it has not been submitted for approval by the Board of the Directors. Any opinions expressed are those of the author and not those of NIDDKD or NBER. The views expressed herein are those of the author(s) and do not necessarily reflect the views of the National Bureau of Economic Research.

(C2006 by Inas Rashad. All rights reserved. Short sections of text, not to exceed two paragraphs, may be quoted without explicit permission provided that full credit, including (C) notice, is given to the source. 
Structural Estimation of Caloric Intake, Exercise, Smoking, and Obesity

Inas Rashad

NBER Working Paper No. 11957

January 2006

JEL No. I10, I12

\begin{abstract}
$\underline{\text { ABSTRACT }}$
The escalating rate of obesity in the US highlights the importance of understanding the causes for this rise. In this paper I employ the First, Second, and Third National Health and Nutrition Examination Surveys to estimate a structural model of the determinants of adult obesity. To control for the potential endogeneity of some explanatory variables, such as caloric intake (adjusted for activity level) and smoking, a set of reduced form equations for these outcomes is estimated simultaneously with the obesity equation. To identify each equation, I use an array of state-level characteristics as instrumental variables. Trends in these variables shed light on the sources of the rapid increase in obesity since 1980.

Inas Rashad

Georgia State University

AYSPS 529

P.O. Box 3992

Atlanta, GA 30302-3992

and NBER

irashad@gsu.edu
\end{abstract}




\section{Introduction}

According to the National Health and Nutrition Examination Survey, the percentage of individuals classified as obese in the United States increased by 67 percent between 1971 and 1994, my period of analysis, with most of this increase occurring during the 1980s. Obesity is the second most important cause of premature death (McGinnis and Foege, 1993; Allison et al., 1999), a statement still supported by the Centers for Disease Control despite their recent downward correction to the death toll attributed to obesity (Mokdad et al., 2005). While certain foods can influence hormones and genes, the increase in obesity probably does not reflect a change in the genetic make-up of the US, since the gene pool did not change significantly between 1990 and 1994 (Koplan and Dietz, 1999). The way our built environment looks is very different from the way it looked just over two decades ago, largely due to advancements in technology. This paper explores the idea that the recent rapid increase in obesity rates is due to economic changes that have in turn changed the amount that Americans eat, exercise, smoke, and do other things that affect their weight. These changes, while advantageous in numerous ways, have nevertheless had negative health consequences. In addition, since demographic characteristics and socioeconomic status influence overweight and obesity, I consider the effect of demographic changes on trends in obesity.

In order to study the determinants of a person's body mass index, which is most often used in measuring obesity, I employ pooled micro-level data from the First, Second, and Third National Health and Nutrition Examination Surveys. I augment these data using state-level data on the price of a restaurant meal, the cigarette tax, average January and July temperatures, and clean indoor air laws. 


\section{Background}

Obesity and sedentary lifestyles are second only to smoking as the leading cause of premature death (McGinnis and Foege, 1993; Allison et al., 1999). They have been linked to coronary heart disease, stroke, high blood pressure, cancers of the colon, breast and prostate, and diabetes (Must et al., 1999; Mokdad et al., 2003). Obesity has also been associated with high cholesterol, menstrual irregularities, pregnancy complications, and psychological disorders such as depression (NIDDKD, 1996). Type II diabetes, once termed adult-onset diabetes, is now not uncommon in children as a result of the obesity epidemic (Freedman et al., 1999). Recently obesity in adulthood has been shown to reduce life expectancy, especially among persons overweight in their youth (Peeters et al., 2003; Fontaine et al., 2003). Economic costs related to overweight and obesity were estimated to be $\$ 99.2$ billion as of 1995 (Wolf and Colditz, 1998), and more recently this estimate has risen to $\$ 117$ billion (USDHHS, 2001). This is especially a major concern for the public, as obesity-related illnesses have contributed to the overall growth in health care spending (Thorpe et al., 2004). Social costs of obesity being higher than private costs are grounds for possible government intervention. ${ }^{1}$

There has been much debate as to what constitutes a proper diet, and recently the USDA's Food Guide Pyramid was replaced with an alternative that stresses vitamin intake, the intake of whole wheat foods, and exercise, the so-called Healthy Eating Pyramid (McCullough et al., 2002; Willett, 2001). Excess carbohydrates in the body have been shown to be converted to fat. Measurements of the glycemic index in the body, which measures the rate of carbohydrate absorption after a meal, has shed light on

\footnotetext{
${ }^{1}$ See Rashad and Grossman (2004) for a discussion of the role of the government and possible policy implications of obesity.
} 
the importance of controlling the intake of carbohydrates as well as that of fat, a high glycemic index being what contributes to obesity (Ford and Liu, 2001; Ludwig, 2002). Since the carb-to-lipid ratio might not be so important, it seems to make more sense to focus on total caloric intake rather than, say, intake of calories from fat. However, there is still some potential concern about the origin of calories, that not all calories are the same.

Money spent on weight-loss drugs has largely contributed to increasing the costs of obesity, as drugs intended to reduce weight have become popular, with a rapid increase since 1990. Surgeries such as gastric bypass surgery are only recommended for the morbidly obese and have numerous surgical risks associated with them. In addition, patients undergoing surgery often do not achieve their desired weight and are put under lifelong medical surveillance (Livingston, 2002; Brolin, 2002). More is being studied about genes and hormones that play a role in regulating body weight. Ghrelin, a hormone primarily produced in the stomach, increases food intake and is strongly responsible for why dieters often gain weight that they have lost (Cummings et al., 2002). The body interprets dieting as starving, and increases its secretion of ghrelin, slowing down metabolism. Sure enough, severely elevated or lowered body weight is associated with offsetting metabolic processes that oppose the maintenance of an altered body weight (Leibel et al., 1995). Low levels of leptin are also associated with obesity (Heymsfield et al., 1999). Injecting obese subjects with leptin as a cure is being looked into. ${ }^{2}$

\footnotetext{
2 This has largely been ineffective as the severely overweight tend to be leptin-resistant. One recent study by Spiegel et al. (2004) has found that lack of sleep in young men tends to reduce leptin levels and increase ghrelin levels. Not only does one have more time to eat when one is not sleeping, but increased ghrelin levels trigger hunger.
} 
In analyzing overweight and obesity, I use the body mass index (BMI), measured as weight in kilograms divided by height in meters squared. An obese person is defined as one having a BMI of $30 \mathrm{~kg} / \mathrm{m}^{2}$ or greater. BMI is convenient as it is routinely measured in physical examinations. Yet BMI might overestimate body fat in athletes who have a muscular build and underestimate body fat in older people who have lost muscle mass (NIDDKD, 1996). While this is the case, it is the standard that the Centers for Disease Control use to track obesity over time and will be employed here.

Using the National Health Interview Survey (1976-1994) and the National Longitudinal Survey of Youth (1982-1998), Lakdawalla and Philipson (2002) show that an index of job strenuousness is inversely related to BMI. They suggest that changes in technology over time have been largely responsible for the increase in the obesity rate. As their data contain only self-reported measures of weight and height rather than actual measures, they somewhat correct for this using a method employed by Cawley (1999). This method uses NHANES data, which contain both self-reported and actual measures of weight and height, to obtain age-, gender-, and race-specific corrections. This is also the method used by Chou et al. (2004) in their study using the Behavioral Risk Factor Surveillance System. Yet some have argued that even this correction does not completely eliminate error and, while better than no correction, is not a perfect substitute for actual measures (see, for example, Plankey et al., 1997).

A number of other causes and consequences of obesity have been studied, such as the effect that the degree of urban sprawl has on weight outcomes (Ewing et al., 2003). Cutler et al. (2003) present evidence suggesting that reductions in the time costs of preparing meals at home for certain groups in the population contribute to an increase in 
weight for those groups. Philipson (2001) points out that a shift in the American economy from agriculture to industry has been accompanied by innovations that economize on time spent in the household sector, such as convenience food for consumption. Cawley (1999) has presented evidence that caloric intake is addictive. This is in line with findings that high-density fast food might indeed be addictive (Naik and Moore, 1996; Schlosser, 2001). Fat consumption in the US has increased (Ippolito and Mathios, 1995; Frazeo, 1999). Evidence has also been put forth suggested that obesity is associated with lower wages for women (Averett and Korenman, 1996; Cawley, 2004).

Due to the importance of the obesity epidemic, there is a pressing need for answers as to why its increase has been so rapid, as well as what can be done in order to rectify or reverse this trend.

\section{Analytical Framework}

The model of this paper follows a similar reasoning and theoretical approach as that of Chou et al. (2004). I go further in this paper in that I estimate instrumental variables models and focus on analyzing demographic determinants of obesity. Differences across gender are focused on, as differences in coefficients across gender are significant at the one percent level when tested. I briefly summarize the framework below.

Energy balance at time $\mathrm{t}\left(E_{t}\right)$ is defined as caloric intake $\left(C_{t}\right)$ minus energy expenditure or activity $\left(A_{t}\right)$ :

$$
E_{t}=C_{t}-A_{t}
$$


The body mass index $(B M I)$ is a function of the sum of energy balance in all periods, as well as a vector of variables $(\varepsilon)$ that are specific to an individual and reflect that individual's predisposition towards obesity:

$$
B M I=f\left(\sum_{t} E_{t}, \mathcal{E}\right)
$$

If caloric intake and physical activity offset each other in each period, one would expect the individual to have a constant body weight. The vector of variables $(\varepsilon)$ includes determinants such as education, age, state of residence, race, marital status, and income. These variables can influence either the process by which a person converts caloric intake into caloric expenditure (via activity) or behavior, and thus affect a person's body mass and predisposition towards obesity. Demographic variables such as education, income, marital status, and state of residence are included to see the effects they potentially have on BMI and because there might be mismeasurement in the self-reported values of caloric intake and activity level that might be correlated with these variables (although I attempt to somewhat correct for possible mismeasurement in caloric intake using degree of mismeasurement in BMI). In addition, these demographic variables might be related to calorie composition, as not all calories are the same.

While no one desires to be obese, some people gain more utility out of consuming food than others. People combine the obtaining of goods and services in the market with their own time to achieve objects that enter their utility functions - such as health, entertainment, and the enjoyment of eating palatable food. Energy expenditure is measured by physical activity. The importance of activity is highlighted in a large literature (see, for example, Hill, 1997; Public Health Service, 2001; USDHHS, 2000), and now the recommended regimen has been increased from half an hour of exercise 
three times a week to a full hour (USDHHS, 2000). I expect smoking to be a negative function of BMI, as smoking has been used as a method of weight control (Philipson, 2001; Chou et al., 2004; Fehily et al., 1984; Tomeo et al., 1999). A combination of federal and state tax hikes, clean indoor air laws forbidding smoking in designated areas, and the anti-smoking campaign have caused people to smoke less over time; this may be part of the reason for the increase in BMI over time.

\section{Empirical Implementation}

In order to account for the potential endogeneity of caloric intake, activity level, and smoking, I estimate structural equations where the body mass index is the outcome of interest in addition to models where these variables are treated as exogenous. Whole sample means for the variables I use in my regressions are shown in Table 1. Activityadjusted caloric intake (caloric intake taking activity level and thus calorie needs into account) and smoking, to be defined later, are functions of a vector of instruments $Z$, as well as exogenous variables $X$. Included in $Z$ are state-level variables pertaining to the price of a restaurant meal, the cigarette tax, average January and July temperatures, and clean indoor air laws. I translate equation (2) into an empirical one by estimating the following:

$$
B M I=\alpha_{0}+\alpha_{1} A C+\alpha_{2} S+\alpha_{3} X+u_{1}
$$

Equation (3) represents the primary equation of interest, treating activity-adjusted caloric intake $(A C)$ - to be defined shortly - and smoking $(S)$ as exogenous right-hand side variables. Note that the empirical model focuses on current caloric intake, adjusted for physical activity, rather than accumulated energy balance over time. I also estimate structural equations, where $A C$ and $S$ are treated as endogenous variables and their 
predicted values are obtained after regressing them on all the exogenous variables. Theoretically, since caloric intake, energy expenditure, and smoking are inputs in the production of body mass index, they should be treated as endogenous. The above equations are estimated independently by ordinary least squares (OLS) and by two-stage least squares (TSLS) for the whole sample as well as by gender. Results for BMI as the dependent variable for the whole sample, then separately for males and females, are shown in Table 2. Results by race are shown in Table 3.

The effectiveness of instrumental variables procedures crucially depends on the validity of the instruments. In order to test the validity of the exclusion restrictions (to ensure that the instruments significantly affect activity-adjusted caloric intake and smoking, but not BMI), I employ the overidentification test suggested by Davidson and MacKinnon (1993). In this test, the residual of the TSLS model is regressed on all exogenous variables. The value of $r$-squared that results, when multiplied by the number of observations, follows a chi-square distribution with degrees of freedom equal to the degree of overidentification. The null is that the instruments are valid. In all cases the null hypothesis could not be rejected at the one percent level, suggesting that the instruments were valid. (Chi-squared values for overidentification tests are given in Tables 2 and 3. The one percent chi-squared value for 10 degrees of freedom - twelve instruments minus two RHS endogenous variables - is 23.21. All chi-squared values are below this, indicating valid instruments.) I also check that the instruments are jointly significant in first-stage equations, and find that they are at the one percent level. (Fvalues and their corresponding significance levels are given in Table 4, which shows first-stage results. First-stage results are not reported by race, yet F-values for the 
instruments by race are shown in Table 3.) Durbin-Wu-Hausman tests for the consistency of the OLS models relative to the TSLS models reveal that the OLS models are consistent at the one percent level. (Significance levels for Durbin-Wu-Hausman tests are reported in Tables 2 and 3.)

Micro-level data from confidential versions of the First, Second, and Third National Health and Nutrition Examination Surveys (NHANES I, II, and III, respectively) are used in this analysis. All three surveys are national samples of the population of the United States and were conducted by the National Center for Health Statistics; NHANES I between 1971 and 1975; NHANES II between 1976 and 1980; and NHANES III between 1988 and 1994. Most states of the United States are represented in each survey. I focus in this paper on all adults 17 years of age and older, who typically control their caloric intake.

Each subject in the surveys received a detailed physical examination including measurement of height and weight. Caloric intake was computed from detailed food consumption during the previous 24 hours reported by the respondent. Since this is a self-reported variable, and likely to have similar under- and over-reporting as BMI, I adjust caloric intake by multiplying it by the ratio of actual to self-reported BMI. ${ }^{3}$ Caloric intake is further adjusted to take into account caloric needs based on reported physical activity. One of the survey questions I use to measure physical activity is, "In your usual day, aside from recreation, how active are you?" for NHANES I and NHANES II (answer choices are very active, moderately active, and quite inactive), and

\footnotetext{
${ }^{3}$ While this is not a perfect adjustment, it somewhat repairs the error in self-reported caloric intake. While questions on weight and height are asked of individuals and not BMI per se, respondents tend to overreport height and underreport weight, yielding a downward-biased BMI (Rashad, 2004). That being said, the correlation between caloric intake and adjusted caloric intake is over 0.99 .
} 
"Compared with most (men/women) your age, would you say you are more active, less active, or about the same?" for NHANES III. ${ }^{4}$

NHANES I and II also ask similar questions on how active respondents are in recreation. NHANES III has more detailed physical activity variables than either NHANES I or NHANES II; indicators for a variety of activities are given as well as the number of times each activity was performed in the past month. The activities are walking a mile without stopping, jogging, riding a bicycle, swimming, aerobics, dancing, calisthenics, garden work, lifting weights, and other exercise. (Respondents are allowed to choose up to four more types of exercise from a detailed list.) These activities were assigned intensity ratings according to a coding scheme developing by Ainsworth et al., (1993); intensity is measured as the ratio of metabolic rate when engaged in the activity to resting metabolic rate. Table 5 shows how increased intensity is correlated with a lower BMI. For the recreation portion of physical activity measurement, I therefore use the question, "In your usual day, aside from recreation, how active are you?" for NHANES I and II (answer choices are, again, very active, moderately active, and quite inactive) and create an analogous variable to the recreation variable in NHANES I and NHANES II by using activity intensity in NHANES III.

I use activity-adjusted caloric intake as caloric intake and activity are likely to be strongly correlated, and proceed as follows. If activity intensity is less than 50 , the respondent is inactive in recreation; if between 50 and 149.9, moderately active; and if 150 or greater very active. Thus an alternative way to run the regression, rather than

\footnotetext{
${ }^{4}$ I recognize the possible shortcomings of using answers to a slightly differently-phrased question for the same variable, especially since the question in NHANES III is a relative one. NHANES III has much more detailed data on activity intensity, which I incorporate into the recreation portion of physical activity measurement.
} 
including caloric intake and activity level on the right-hand side, is to make use of the Harris-Benedict (1919) multipliers in order to adjust caloric intake for activity level. I classify multipliers for activity according to the following guidelines:

Sedentary: $\quad 1.2$ (inactive in both recreation and work)

Lightly Active: 1.375 (inactive in one, active in the other)

Moderately Active: 1.55 (active in both, OR inactive in one, very active in the other)

Very Active: $\quad 1.725$ (very active in one, active in the other)

Extra Active: $\quad 1.9$ (very active in both).

I thus divide caloric intake by the above numbers according to activity category in both recreation and work.

Harris-Benedict equations have largely been used in the medical literature to predict basal metabolic rate (BMR) for a person based on his or her age, weight, height, and gender. While they may overestimate BMR in obese people and possibly female anorectics, they are still the most commonly used equations for clinical and research purposes (Frankenfield et al., 1998; Kien and Ugrasbul, 2004; Marra et al., 2002). The equations themselves are not used here but, rather, simply the activity multipliers are employed to obtain a measure of caloric intake that takes into account the individual's level of activity.

Caloric intake not only influences BMI but is also likely to be influenced by BMI, especially if caloric intake is habituating. For similar reasons as those for caloric intake, physical activity is also likely to be endogenous. I identify activity-adjusted caloric intake by using the state-level price of a restaurant meal, and average January and July temperatures. Frequency of fast food restaurant use has been shown to be associated with 
higher fat intake and greater body weight (French et al., 2000; Rolls and Hammer, 1995; Public Health Service, 2001), as fast food restaurants serve especially large portions (Nielsen and Popkin 2003). According to the Census of Retail Trade, the per capita number of restaurants increased by 61 percent between 1972 and 1997. The ready availability of cheap, prepared food greatly reduces the time cost associated with eating, especially important now that more females have entered the labor force. Information on the average price of a meal at restaurants is collected from the Census of Retail Trade (Bureau of the Census, various years). The Census of Retail Trade is part of the Economic Census and is collected every five years. The data I use are from 1972, 1977, 1982, 1987, 1992, and 1997. Fast food restaurants correspond to the Census category refreshment places while full service restaurants correspond to the Census category restaurants and lunchrooms. In 1997 this classification system changed; refreshment places were analogous to limited service restaurants, and restaurants and lunchrooms were analogous to full service restaurants. Since these categories did not exactly overlap, I use a correction based on national data that the Census collected in 1997 for both categories. Data for years not covered are linearly interpolated and extrapolated. The restaurant price variable takes the average of the prices of the combination of fast food and full service restaurants, weighted by the number of restaurants in each category. Outside temperature is likely to influence an individual's level of activity. Temperatures used pertain to the mean 1976 temperature in the state of residence. Information on January and July temperatures is from the 1998 Area Resource File.

Smoking, which tends to increase metabolism and suppress appetite, thus having a negative effect on BMI, is measured using a dichotomous indicator for whether or not 
the person is currently smoking. To account for the potential endogeneity of smoking, included among the instruments are cigarette taxes and clean indoor air laws. Higher cigarette taxes lead to lower cigarette consumption, while clean indoor air laws discourage smoking indoors (Tauras and Chaloupka, 1999; Ross et al., 2005; Chaloupka and Wechsler, 1997; Chaloupka and Saffer, 1992). The cigarette tax is taken from the Tax Burden on Tobacco (Orzechowski and Walker, 2002). Clean indoor air laws are taken from the Centers for Disease Control and Prevention website (http://www.cdc.gov). The four indoor air laws pertain to government workplaces, private workplaces, restaurants, and other places.

Since structural models are difficult to estimate, caution should be taken with interpretation. Instruments, while passing tests for validity, might nevertheless be slightly weak. ${ }^{5}$ In addition, since non-random measurement error is likely to exist in the self-reported, potentially endogenous variables, instrumental variables methods will not necessarily eliminate this bias. I estimate ordinary least squares models, where I treat activity-adjusted caloric intake and smoking as exogenous, in addition to two-stage least squares models.

\section{Results}

Table 1 shows definitions, means, and standard deviations of the variables. They are based on the sample of 28,696 that emerges when observations with missing values are deleted. NHANES sample weights are employed in all regressions, as well as state and year controls. To account for the aggregate nature of the instruments, standard errors allow for state clustering. Table 2 shows results for the whole sample and separately by

\footnotetext{
${ }^{5}$ One indication of weak instruments is obtaining low F-values when testing for their joint significance in the first stage (Bound et al., 1995). As seen in Tables 3 and 4, not only are the instruments highly significant, but their F-values are very high as well.
} 
gender for BMI as the dependent variable. I see a consistent pattern in terms of the strong positive effect of caloric intake and the strong negative effect of smoking on BMI in ordinary least squares models. Older people, blacks, Hispanic females, and married males are more likely to have a higher BMI, while those with a college education, and females with a higher household income, are more likely to have a lower BMI. Although tests reveal OLS models to be consistent, two-stage least squares models show how the strong effects of caloric intake and smoking seem to disappear after controlling for their potential endogeneity, with the exception of caloric intake for females. This is notable, as it was the female who most frequently prepared meals at home, whereas now there is less time and energy available for activities such as food preparation. Increases in hours worked and declines in real wage rates have increased the demand for inexpensive, prepared food, which has increased caloric intake. At the same time, work has become more sedentary. Note also that, although caloric intake is positive but insignificant for males in TSLS regressions, marital status is significant for males (but not for females). With 69 percent of males in the sample married, this could be strongly correlated with caloric intake. In addition, household income is associated with a higher BMI for males (but a lower BMI for females); if males earn most of the household income, this effect could be partially capturing the more sedentary nature of higher-income jobs, as there is likely to be mismeasurement in self-reported activity. I also ran regressions where I only instrument for smoking using the cigarette tax and clean indoor air laws, and smoking consistently loses its effect on BMI when controlling for its endogeneity. This could be because smoking is correlated with other unhealthy behaviors, or because, if people are smoking to lose weight, then they might already be overweight to begin with. Two-stage 
least squares models reveal that behavior within the same period might not have a strong effect, as accumulation over time is not being accounted for.

Table 3 shows differences across race. Here smoking has a negative, significant impact on BMI for Hispanics in two-stage least squares models. Black males have significantly lower BMIs than black females in both ordinary least squares and two-stage least squares models. Household income appears to lower BMI for whites but not for blacks or Hispanics.

First-stage regression results for the whole sample as well as by gender are reported in Table 4. The instruments are jointly very significant with high F-values. Values of r-squared are not too high, ranging from 0.07 to 0.19 , but are typical of individual-level regressions in the health economics literature. The effect of the price of a restaurant meal on smoking for females is $(0.235-0.024 * 2 * 4.872)=0.001$, indicating a positive effect of price on smoking, as expected. ${ }^{6}$ The cigarette tax has a consistently negative effect on smoking. A consistently negative and significant effect of indoor air laws in restaurants on caloric intake might be indicative of unhealthy behaviors being complementary, especially in social situations, while a positive and significant effect in private workplaces might suggest the substitutability of caloric intake for smoking.

\section{Discussion}

Obesity is an escalating problem in the United States. Caloric intake, which is habituating, and lack of physical activity, or a sedentary lifestyle, are prime contributors to this epidemic. An unforeseen contributor is possibly the decrease in the percentage of

\footnotetext{
${ }^{6}$ The average price for a restaurant meal for females is 4.872 .
} 
people who smoke. ${ }^{7}$ The ready availability of inexpensive restaurants has not only caused people to consume more, but has made them less active - less likely to prepare food at home or travel further distances to obtain a healthy meal. The decrease in food prices has allowed for the prevalence of restaurants and the availability of inexpensive junk food, thus facilitating increased caloric intake; man is conditioned to consume because, historically, this has been a means for survival.

Pooled data from NHANES, spanning the 1971-1994 time period, show caloric intake, activity level, and smoking to be important determinants of obesity. These determinants are not as important when using confidential versions of the data to merge state-level variables to account for the endogeneity of these determinants, indicating that accumulated behaviors over time and genetic factors might have a greater influence. Reduced-form models reveal that the price of a restaurant meal and the cigarette tax have significant effects in determining obesity. I find that increases in caloric intake increase female BMI, and that education and income in general lower it; married men and men with higher incomes also tend to have a higher BMI. Increases in the availability of restaurants and lowered food prices contribute to the epidemic.

\footnotetext{
${ }^{7}$ Saying that a factor, such as smoking, contributes to escalating BMI rates is clearly not suggestive of picking up that behavior in order to reverse the trend of obesity, substituting one unhealthy behavior for another. Those who stop smoking, however, have been told to watch their weight.
} 


\section{References}

Ainsworth, B., Haskell, W., \& Leon, A. (1993). Compendium of Physical Activities: Classification of Energy Costs of Human Physical Activities. Medicine and Science in Sports and Exercise, 25, 71-80.

Allison, D. B., Fontaine, K. R., Manson, J. E., Stevens, J., \& VanItallie, T. B. (1999). Annual Deaths Attributable to Obesity in the United States. Journal of the American Medical Association, 282, 1530-1538.

Averett, S. \& Korenman, S. (1996). The Economic Reality of the Beauty Myth. Journal of Human Resources, 31, 304-330.

Bound, J., Jaeger, D., \& Baker, R. (1995). Problems with Instrumental Variables Estimation When the Correlation Between the Instruments and the Endogenous Explanatory Variable Is Weak. Journal of the American Statistical Association, 90, 443-450.

Brolin, R. E. (2002). Bariatric Surgery and Long-term Control of Morbid Obesity. Journal of the American Medical Association, 288, 2793-2796.

Bureau of the Census (1976, 1986, 1989, 1994, and 2000). 1972, 1982, 1987, 1992, and 1997 Census of Retail Trade, Washington, DC: US Government Printing Office.

Cawley, J. (1999). Addiction, Calories, and Body Weight. PhD dissertation, University of Chicago.

Cawley, J. (2004). The Impact of Obesity on Wages. Journal of Human Resources, 39, 451-474.

Chaloupka, F. J. \& Saffer, H. (1992). Clean Indoor Air Laws and the Demand for Cigarettes. Contemporary Economic Policy, 10, 72-83.

Chaloupka, F. J. \& Wechsler, H. (1997). Price, Tobacco Control Policies and Smoking Among Young Adults. Journal of Health Economics, 16, 359-373.

Chou, S., Grossman, M., \& Saffer, H. (2004). An Economic Analysis of Adult Obesity: Results from the Behavioral Risk Factor Surveillance System. Journal of Health Economics, 23, 565-587.

Cummings, D. E., Weigle, D. S., Frayo, R. S., Breen, P. A., Ma, M. K., Dellinger, E. P., \& Purnell, J. Q. (2002). Plasma Ghrelin Levels After Diet-Induced Weight Loss or Gastric Bypass Surgery. New England Journal of Medicine, 346, 1623-1630.

Cutler, D. M., Glaeser, E. L., \& Shapiro, J. M. (2003). Why Have Americans Become More Obese? Journal of Economic Perspectives, 17, 93-118.

Davidson, R. \& MacKinnon, J. (1993). Estimation and Inference in Econometrics, New 
York: Oxford.

Ewing, R., Schmid T, Killingsworth, R., Zlot, A., \& Raudenbush, S. (2003). Relationship Between Urban Sprawl and Physical Activity, Obesity, and Morbidity. American Journal of Health Promotion, 18, 47-57.

Fehily, A., Phillips, K., \& Yarnell, J. (1984). Diet, Smoking, Social Class, and Body Mass Index in the Caerphilly Heart Disease Study. American Journal of Clinical Nutrition, 40, 827-833.

Fontaine, K. R., Redden, D. T., Wang, C., Westfall, A. O., \& Allison, D. B. (2003). Years of Life Lost Due to Obesity. Journal of the American Medical Association, 289, 187-193.

Ford, E. S. \& Liu, S. (2001). Glycemic Index and Serum High-Density Lipoprotein Cholesterol Concentration Among US Adults. Archives of Internal Medicine, 161, 572-576.

Frankenfield, D. C., Muth, E. R., \& Rowe, W. A. (1998). The Harris-Benedict Studies of Human Basal Metabolism: History and Limitations. Journal of the American Dietetic Association, 98, 439-445.

Frazao, E. (1999). America's Eating Habits: Changes and Consequences. Information Bulletin AIB-750. Washington DC: US Department of Agriculture.

Freedman, D., Dietz, W., Srinivasan, S., \& Berenson G.S. (1999). The Relation of Overweight to Cardiovascular Risk Factors Among Children and Adolescents: The Bogalusa Heart Study. Pediatrics, 103, 1175-1182.

French, S., Harnack, L., \& Jeffery, R. (2000). Fast Food Restaurant Use Among Women in the Pound of Prevention Study: Dietary, Behavioral, and Demographic Correlates. International Journal of Obesity, 24, 1353-1359.

Harris, J. A. \& Benedict, F. G. (1919). A Biometric Study of Basal Metabolism in Man, Washington: Carnegie Institution.

Heymsfield, S. B., Greenberg, A. S., Fujioka, K., Dixon, R. M., Kushner, R., Hunt, T., Lubina, J. A., Patane, J., Self, B., Hunt, P., \& McCamish, M. (1999).

Recombinant Leptin for Weight Loss in Obese and Lean Adults: A Randomized, Controlled Dose-Escalation Trial. Journal of the American Medical Association, 282, 1568-1575.

Hill, J. (1997). Physical Activity, Body Weight, and Body Fat Distribution. In A. Leon (ed.), Physical Activity and Cardiovascular Health: A National Consensus, Champaign, Illinois: Human Kinetics.

Ippolito, P. M. \& Mathios, A. D. (1995). Information and Advertising: The Case of Fat Consumption in the United States. American Economic Review, 85, 91-95. 
Kien, C. L. \& Ugrasbul, F. (2004). Prediction of Daily Energy Expenditure During a Feeding Trial Using Measurements of Resting Energy Expenditure, Fat-Free Mass, or Harris-Benedict Equations. American Journal of Clinical Nutrition, 80, 876-880.

Koplan, J. P. \& Dietz, W. H. (1999). Caloric Imbalance and Public Health Policy. Journal of the American Medical Association, 282, 1579-1581.

Lakdawalla, D. \& Philipson, T. (2002). The Growth of Obesity and Technological Change: A Theoretical and Empirical Examination. NBER Working Paper No. 8946.

Leibel, R. L., Rosenbaum, M., \& Hirsch, J. (1995). Changes in Energy Expenditure Resulting from Altered Body Weight. New England Journal of Medicine, 332, 621-628.

Livingston, E. H. (2002). Obesity and Its Surgical Management. American Journal of Surgery, 184, 103-113.

Ludwig, D. S. (2002). The Glycemic Index: Physiological Mechanisms Relating to Obesity, Diabetes, and Cardiovascular Disease. Journal of the American Medical Association, 287, 2414-2423.

Marra, M., Polito, A., De Fillippo, E., Cuzzolaro, M., Ciarapica, D., Contaldo, F., \& Scalfi, L. (2002). Are the General Equations to Predict BMR Applicable to Patients with Anorexia Nervosa? Eating and Weight Disorders, 7, 53-59.

McCullough, M., Feskanich, D., Stampfer, M. J., Giovannucci, E. L., Rimm, E. B., Hu, F. B., Spiegelman, D., Hunter, D. J., Colditz, G. A., \& Willett, W. C. (2002). Diet Quality and Major Chronic Disease Risk in Men and Women: Moving Toward Improved Dietary Guidance. American Journal of Clinical Nutrition, 76, 12611271.

McGinnis, J. M. \& Foege, W. H. (1993). Actual Causes of Deaths in the United States. Journal of the American Medical Association, 270, 2207-2212.

Mokdad, A. H., Ford, E. S., Bowman, B. A., Dietz, W. H., Vinicor, F., Bales, V. S., \& Marks, J. S. (2003). Prevalence of Obesity, Diabetes, and Obesity-Related Health Risk Factors, 2001. Journal of the American Medical Association, 289, 76-79.

Mokdad, A. H., Marks, J. S., Stroup, D. F., \& Gerberding, J. L. (2005). Correction: Actual Causes of Death in the United States, 2000. Journal of the American Medical Association, 293, 293-294.

Must, A., Spadano, J., Coakley, E. H., Field, A. E., Colditz, G., \& Dietz, W. H. (1999). The Disease Burden Associated With Overweight and Obesity. Journal of the American Medical Association, 282, 1523-1529. 
Naik, N. Y. \& Moore, M. J. (1996). Habit Formation and Intertemporal Substitution in Individual Food Consumption. Review of Economics and Statistics, 78, 321-328.

National Institute of Diabetes and Digestive and Kidney Diseases (1996). Statistics Related to Overweight and Obesity. Washington DC: US Government Printing Office.

Nielsen, S. J. \& Popkin, B. M. (2003). Patterns and Trends in Food Portion Sizes, 19771998. Journal of the American Medical Association, 289, 450-453.

Orzechowski, W. \& Walker, R. (2002). The Tax Burden on Tobacco: Volume 36, 2001. Arlington, VA: Orzechowski and Walker.

Peeters, A., Barendregt, J. J., Willekens, F., Mackenbach, J. P., Al Mamum, A., \& Bonneux, L. (2003). Obesity in Adulthood and Its Consequences for Life Expectancy: A Life-Table Analysis. Annals of Internal Medicine, 138, 24-32.

Philipson, T. (2001). The World-Wide Growth in Obesity: An Economic Research Agenda. Health Economics, 10, 1-7.

Plankey, M. W., Stevens, J., Flegal, K. M., \& Rust, P. F. (1997). Prediction Equations Do Not Eliminate Systematic Error in Self-Reported Body Mass Index. Obesity Research, 5, 308-314.

Public Health Service (2001). The Surgeon General's Call To Action To Prevent and Decrease Overweight and Obesity. Washington, DC: US Government Printing Office.

Rashad, I. (2004). Essays in the Economics of Obesity. PhD dissertation, City University of New York Graduate Center.

Rashad, I. \& Grossman, M. (2004). The Economics of Obesity. Public Interest, 156, 104112.

Rolls, B. \& Hammer, V. (1995). Fat, Carbohydrate, and the Regulation of Energy Intake. American Journal of Clinical Nutrition, 62 (suppl), 195S-202S.

Ross, H., Powell, L. M., Tauras, J. A, \& Chaloupka, F. J. (2005). New Evidence on Youth Smoking Behavior based on Experimental Price Increases. Contemporary Economic Policy, 23, 195-210.

Schlosser, E. (2001). Fast Food Nation: The Dark Side of the All-American Meal. Boston: Houghton Mifflin Company.

Spiegel, K., Tasali, E., Penev, P., \& Van Cauter, E. (2004). Sleep Curtailment in Healthy Young Men Is Associated with Decreased Leptin Levels, Elevated Ghrelin Levels, and Increased Hunger and Appetite. Annals of Internal Medicine, 141, 846-850. 
Tauras, J. A. \& Chaloupka, F. J. (1999). Price, Clean Indoor Air, and Cigarette Smoking: Evidence from the Longitudinal Data for Young Adults. NBER Working Papers 6937.

Thorpe, K.E., Florence, C.S., \& Joski, P (2004). Which Medical Conditions Account For the Rise In Health Care Spending? Health Affairs, W4-437-445.

Tomeo, C. A., Field, A. E., Berkey, C. S., Colditz, G. A., \& Frazier, A. L. (1999). Weight Concerns, Weight Control Behaviors, and Smoking Initiation. Pediatrics, 104, 918-924.

US Department of Health and Human Services (2000). Healthy People 2010: National Health Promotion and Disease Objectives. Washington DC: US Government Printing Office.

US Department of Health and Human Services (2001). The Surgeon General's Call to Action to Prevent and Decrease Overweight and Obesity. Washington DC: US Government Printing Office.

Willett, W. C. (2001). Eat, Drink, and Be Healthy: The Harvard Medical School Guide to Healthy Eating. New York: Simon and Schuster.

Wolf, A. \& Colditz, G. (1998). Current Estimates of the Economic Cost of Obesity in the United States. Obesity Research, 6, 97-106. 


\section{Table 1}

Definitions, Means, and Standard Deviations of Variables for Whole Sample

\begin{tabular}{|c|c|c|}
\hline Variable & Definition & $\begin{array}{c}\text { Mean and Standard } \\
\text { Deviation }\end{array}$ \\
\hline Body mass index & $\begin{array}{l}\text { Weight in kilograms divided by height in } \\
\text { meters squared }\end{array}$ & $\begin{array}{l}25.689 \\
(5.279)\end{array}$ \\
\hline Caloric intake & $\begin{array}{l}\text { Activity-adjusted kilocalories consumed in } \\
\text { one day, based on } 24 \text {-hour recall }\end{array}$ & $\begin{array}{r}1,533.030 \\
(779.427)\end{array}$ \\
\hline Smoking & $\begin{array}{l}\text { Dichotomous variable that equals } 1 \text { if } \\
\text { respondent smokes, and } 0 \text { otherwise }\end{array}$ & $\begin{array}{c}0.353 \\
(0.478)\end{array}$ \\
\hline Black non-Hispanic & $\begin{array}{l}\text { Dichotomous variable that equals } 1 \text { if } \\
\text { respondent is black but not Hispanic }\end{array}$ & $\begin{array}{c}0.104 \\
(0.306)\end{array}$ \\
\hline Hispanic & $\begin{array}{l}\text { Dichotomous variable that equals } 1 \text { if } \\
\text { respondent is Hispanic }\end{array}$ & $\begin{array}{c}0.066 \\
(0.248)\end{array}$ \\
\hline Other race & $\begin{array}{l}\text { Dichotomous variable if respondent's race is } \\
\text { other than white, black, or Hispanic }\end{array}$ & $\begin{array}{c}0.025 \\
(0.156)\end{array}$ \\
\hline Male & $\begin{array}{l}\text { Dichotomous variable that equals } 1 \text { if } \\
\text { respondent is male }\end{array}$ & $\begin{array}{c}0.496 \\
(0.500)\end{array}$ \\
\hline Elementary & $\begin{array}{l}\text { Dichotomous variable that equals } 1 \text { if } \\
\text { respondent completed } 8 \text { years of formal } \\
\text { schooling }\end{array}$ & $\begin{array}{c}0.055 \\
(0.227)\end{array}$ \\
\hline Some high school & $\begin{array}{l}\text { Dichotomous variable that equals } 1 \text { if } \\
\text { respondent completed at least } 9 \text { years but } \\
\text { fewer than } 12 \text { years of formal schooling }\end{array}$ & $\begin{array}{c}0.163 \\
(0.369)\end{array}$ \\
\hline High school graduate & $\begin{array}{l}\text { Dichotomous variable that equals } 1 \text { if } \\
\text { respondent completed exactly } 12 \text { years of } \\
\text { formal schooling }\end{array}$ & $\begin{array}{c}0.352 \\
(0.477)\end{array}$ \\
\hline Some college & $\begin{array}{l}\text { Dichotomous variable that equals } 1 \text { if } \\
\text { respondent completed at least } 13 \text { years but } \\
\text { fewer than } 16 \text { years of formal schooling }\end{array}$ & $\begin{array}{c}0.183 \\
(0.387)\end{array}$ \\
\hline College graduate & $\begin{array}{l}\text { Dichotomous variable that equals } 1 \text { if } \\
\text { respondent graduated from college }\end{array}$ & $\begin{array}{c}0.170 \\
(0.376)\end{array}$ \\
\hline Married & $\begin{array}{l}\text { Dichotomous variable that equals } 1 \text { if } \\
\text { respondent is married }\end{array}$ & $\begin{array}{c}0.643 \\
(0.479)\end{array}$ \\
\hline Divorced & $\begin{array}{l}\text { Dichotomous variable that equals } 1 \text { if } \\
\text { respondent is divorced or separated }\end{array}$ & $\begin{array}{c}0.091 \\
(0.288)\end{array}$ \\
\hline Widowed & $\begin{array}{l}\text { Dichotomous variable that equals } 1 \text { if } \\
\text { respondent is widowed }\end{array}$ & $\begin{array}{c}0.054 \\
(0.226)\end{array}$ \\
\hline Household income & $\begin{array}{l}\text { Real household income in tens of thousands } \\
\text { of 1982-84 dollars }\end{array}$ & $\begin{array}{c}3.007 \\
(2.431)\end{array}$ \\
\hline Age & Age of respondent & $\begin{array}{c}41.741 \\
(16.390)\end{array}$ \\
\hline
\end{tabular}




\section{Table 1 (continued)}

Definitions, Means, and Standard Deviations of Variables

\begin{tabular}{|c|c|c|}
\hline Variable & Definition & $\begin{array}{l}\text { Mean and Standard } \\
\text { Deviation }\end{array}$ \\
\hline Restaurant price & $\begin{array}{l}\text { Average real fast-food and full-service } \\
\text { restaurant meal price in respondent's state of } \\
\text { residence in 1982-84 dollars }\end{array}$ & $\begin{array}{c}4.880 \\
(0.695)\end{array}$ \\
\hline Cigarette tax & Real state cigarette tax in $1982-84$ cents & $\begin{array}{l}20.567 \\
(8.938)\end{array}$ \\
\hline January temperature & $\begin{array}{l}\text { Average January temperature in degrees } \\
\text { Fahrenheit }\end{array}$ & $\begin{array}{l}33.168 \\
(12.492)\end{array}$ \\
\hline July temperature & $\begin{array}{l}\text { Average July temperature in degrees } \\
\text { Fahrenheit }\end{array}$ & $\begin{array}{l}73.236 \\
(11.531)\end{array}$ \\
\hline Private & $\begin{array}{l}\text { Dichotomous variable that equals } 1 \text { if } \\
\text { smoking is prohibited in private workplaces in } \\
\text { respondent's state of residence }\end{array}$ & $\begin{array}{c}0.155 \\
(0.362)\end{array}$ \\
\hline Government & $\begin{array}{l}\text { Dichotomous variable that equals } 1 \text { if } \\
\text { smoking is prohibited in state and local } \\
\text { government workplaces in respondent's state } \\
\text { of residence }\end{array}$ & $\begin{array}{c}0.215 \\
(0.411)\end{array}$ \\
\hline Restaurant & $\begin{array}{l}\text { Dichotomous variable that equals } 1 \text { if } \\
\text { smoking is prohibited in restaurants in } \\
\text { respondent's state of residence }\end{array}$ & $\begin{array}{c}0.314 \\
(0.464)\end{array}$ \\
\hline Other & $\begin{array}{l}\text { Dichotomous variable that equals } 1 \text { if } \\
\text { smoking is prohibited in other public places } \\
\text { such as elevators, public transportation, and } \\
\text { theaters in respondent's state of residence }\end{array}$ & $\begin{array}{c}0.364 \\
(0.481)\end{array}$ \\
\hline
\end{tabular}

Standard deviation is reported in parentheses. Sample size is 28,696 . NHANES sample weights are used in calculating the mean and standard deviation. 


\section{Table 2}

Body Mass Index Regressions, Whole Sample and By Gender, Persons 17 Years of Age and Older

\begin{tabular}{|c|c|c|c|c|c|c|}
\hline \multirow[t]{2}{*}{ Independent Variables } & \multicolumn{2}{|c|}{ Whole Sample } & \multicolumn{2}{|c|}{ Males } & \multicolumn{2}{|c|}{ Females } \\
\hline & (1) OLS & (2) TSLS & (1) OLS & (2) TSLS & (1) OLS & (2) TSLS \\
\hline Activity-adjusted & $0.0004 * * *$ & 0.002 & $0.0003 * * *$ & 0.001 & $0.001 * * *$ & $0.004 *$ \\
\hline caloric intake & $(5.01)$ & $(1.47)$ & $(3.63)$ & $(0.46)$ & $(2.98)$ & $(1.68)$ \\
\hline Smoking & $\begin{array}{l}-1.318 * * * \\
(15.01)\end{array}$ & $\begin{array}{l}-3.851 \\
(0.96)\end{array}$ & $\begin{array}{l}-1.267 * * * \\
(8.96)\end{array}$ & $\begin{array}{l}-4.827 \\
(1.30)\end{array}$ & $\begin{array}{l}-1.238 * * * \\
(7.79)\end{array}$ & $\begin{array}{l}-6.461 \\
(1.67)\end{array}$ \\
\hline Black & $\begin{array}{l}1.478 * * * \\
(9.80)\end{array}$ & $\begin{array}{l}1.660^{* * * *} \\
(5.31)\end{array}$ & $\begin{array}{l}0.369^{* * * *} \\
(3.57)\end{array}$ & $\begin{array}{r}0.491 \\
(1.46)\end{array}$ & $\begin{array}{l}2.471 * * * \\
(10.19)\end{array}$ & $\begin{array}{l}2.361 * * * \\
(5.84)\end{array}$ \\
\hline Hispanic & $\begin{array}{l}0.686 * * * \\
(3.45)\end{array}$ & $\begin{array}{c}0.411 \\
(0.64)\end{array}$ & $\begin{array}{r}0.253 \\
(0.80)\end{array}$ & $\begin{array}{l}-0.041 \\
(0.07)\end{array}$ & $\begin{array}{l}1.064 * * * \\
(6.63)\end{array}$ & $\begin{array}{c}0.107 \\
(0.16)\end{array}$ \\
\hline Other race & $\begin{array}{l}-1.350 * * * \\
(3.04)\end{array}$ & $\begin{array}{l}-1.353^{* * * *} \\
(2.74)\end{array}$ & $\begin{array}{l}-1.549^{* * * *} \\
(3.95)\end{array}$ & $\begin{array}{l}-1.434 * * * \\
(2.74)\end{array}$ & $\begin{array}{l}-1.257^{* *} \\
(2.08)\end{array}$ & $\begin{array}{l}-1.873^{* *} \\
(2.48)\end{array}$ \\
\hline Male & $\begin{array}{l}0.315^{* * *} \\
(2.25)\end{array}$ & $\begin{array}{l}-0.684 \\
(0.66)\end{array}$ & $x^{2}+2-2$ & 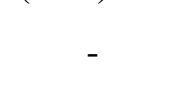 & - & (2 +2 \\
\hline Elementary & $\begin{array}{c}0.031 \\
(0.16)\end{array}$ & $\begin{array}{c}0.032 \\
(0.10)\end{array}$ & $\begin{array}{c}0.167 \\
(0.64)\end{array}$ & $\begin{array}{l}0.253 \\
(1.03)\end{array}$ & $\begin{array}{l}-0.175 \\
(0.53)\end{array}$ & $\begin{array}{l}-0.163 \\
(0.36)\end{array}$ \\
\hline Some high school & $\begin{array}{l}0.136 \\
(0.96)\end{array}$ & $\begin{array}{c}0.153 \\
(0.41)\end{array}$ & $\begin{array}{l}0.192 \\
(1.05)\end{array}$ & $\begin{array}{c}0.258 \\
(0.86)\end{array}$ & $\begin{array}{l}-0.173 \\
(0.63)\end{array}$ & $\begin{array}{r}0.330 \\
(0.83)\end{array}$ \\
\hline High school graduate & $\begin{array}{l}-0.036 \\
(0.24)\end{array}$ & $\begin{array}{l}-0.269 \\
(0.87)\end{array}$ & $\begin{array}{l}0.405^{*} \\
(1.98)\end{array}$ & $\begin{array}{r}0.349 \\
(1.00)\end{array}$ & $\begin{array}{l}-0.740 * * * \\
(3.00)\end{array}$ & $\begin{array}{l}-0.932 * * * \\
(3.15)\end{array}$ \\
\hline Some college & $\begin{array}{l}-0.531 * * * \\
(3.06)\end{array}$ & $\begin{array}{l}-0.970 * * \\
(2.49)\end{array}$ & $\begin{array}{l}0.219 \\
(1.17)\end{array}$ & $\begin{array}{l}-0.200 \\
(0.46)\end{array}$ & $\begin{array}{l}-1.493 * * * \\
(4.32)\end{array}$ & $\begin{array}{l}-2.044 * * * \\
(4.54)\end{array}$ \\
\hline College graduate & $\begin{array}{l}-1.299 * * * \\
(7.09)\end{array}$ & $\begin{array}{l}-1.864 * * \\
(2.69)\end{array}$ & $\begin{array}{l}-0.597 * * * \\
(2.79)\end{array}$ & $\begin{array}{l}-1.303^{*} \\
(1.82)\end{array}$ & $\begin{array}{l}-2.475^{* * * *} \\
(7.39)\end{array}$ & $\begin{array}{l}-3.493 * * * \\
(4.64)\end{array}$ \\
\hline Married & $\begin{array}{l}0.486^{* *} \\
(2.30)\end{array}$ & $\begin{array}{l}0.599 \text { *** } \\
(3.39)\end{array}$ & $\begin{array}{l}0.897 * * * \\
(4.90)\end{array}$ & $\begin{array}{l}1.011^{* * * *} \\
(4.41)\end{array}$ & $\begin{array}{c}0.159 \\
(0.50)\end{array}$ & $\begin{array}{c}0.420 \\
(1.32)\end{array}$ \\
\hline Divorced & $\begin{array}{c}0.079 \\
(0.38)\end{array}$ & $\begin{array}{c}0.419 \\
(0.93)\end{array}$ & $\begin{array}{l}0.130 \\
(0.53)\end{array}$ & $\begin{array}{c}0.677 \\
(1.12)\end{array}$ & $\begin{array}{l}-0.207 \\
(0.73)\end{array}$ & $\begin{array}{c}0.483 \\
(0.98)\end{array}$ \\
\hline Widowed & $\begin{array}{l}0.679 * * \\
(2.25)\end{array}$ & $\begin{array}{l}0.809^{* *} \\
(2.09)\end{array}$ & $\begin{array}{l}0.768^{* * *} \\
(2.13)\end{array}$ & $\begin{array}{l}1.407^{*} \\
(1.96)\end{array}$ & $\begin{array}{l}-0.100 \\
(0.27)\end{array}$ & $\begin{array}{r}0.443 \\
(1.35)\end{array}$ \\
\hline Household income & $\begin{array}{l}-0.203 * * * \\
(2.96)\end{array}$ & $\begin{array}{l}-0.305^{*} \\
(1.91)\end{array}$ & $\begin{array}{l}0.164^{*} \\
(1.90)\end{array}$ & $\begin{array}{c}0.003 \\
(0.01)\end{array}$ & $\begin{array}{l}-0.491 * * * \\
(5.28)\end{array}$ & $\begin{array}{l}-0.640 * * * \\
(3.86)\end{array}$ \\
\hline $\begin{array}{l}\text { Household income } \\
\text { squared }\end{array}$ & $\begin{array}{l}0.014 * * \\
(1.96)\end{array}$ & $\begin{array}{l}0.023^{*} \\
(1.71)\end{array}$ & $\begin{array}{l}-0.017 * * \\
(2.09)\end{array}$ & $\begin{array}{l}-0.005 \\
(0.27)\end{array}$ & $\begin{array}{l}0.037 * * * \\
(3.57)\end{array}$ & $\begin{array}{l}0.051 * * * \\
(3.24)\end{array}$ \\
\hline Age & $\begin{array}{l}0.351^{* * * *} \\
(19.91)\end{array}$ & $\begin{array}{l}0.393^{* * * *} \\
(6.56)\end{array}$ & $\begin{array}{l}0.306^{* * * *} \\
(14.54)\end{array}$ & $\begin{array}{l}0.374 * * * \\
(5.10)\end{array}$ & $\begin{array}{l}0.379 * * * \\
(14.58)\end{array}$ & $\begin{array}{l}0.443 * * * \\
(8.94)\end{array}$ \\
\hline Age squared & $\begin{array}{l}-0.003^{* * *} \\
(18.10)\end{array}$ & $\begin{array}{l}-0.004 * * * \\
(4.07)\end{array}$ & $\begin{array}{l}-0.003 * * * \\
(13.58)\end{array}$ & $\begin{array}{l}-0.004 * * * \\
(3.74)\end{array}$ & $\begin{array}{l}-0.003^{* * *} \\
(12.39) \\
\end{array}$ & $\begin{array}{l}-0.004 * * * \\
(5.83)\end{array}$ \\
\hline
\end{tabular}


Table 2 (continued)

Body Mass Index Regressions, Whole Sample and By Gender, Persons 17 Years of Age and Older

\begin{tabular}{|c|c|c|c|c|c|c|}
\hline \multirow[t]{2}{*}{ Independent Variables } & \multicolumn{2}{|c|}{ Whole Sample } & \multicolumn{2}{|c|}{ Males } & \multicolumn{2}{|c|}{ Females } \\
\hline & (1) OLS & (2) TSLS & (1) OLS & (2) TSLS & (1) OLS & (2) TSLS \\
\hline Intercept & $\begin{array}{l}16.485^{* * * *} \\
(29.57)\end{array}$ & $\begin{array}{l}14.664 * * * \\
(4.90)\end{array}$ & $\begin{array}{l}17.970 \text { *** } \\
(24.58)\end{array}$ & $\begin{array}{l}18.555^{* * * *} \\
(5.32)\end{array}$ & $\begin{array}{l}15.589 * * * \\
(22.18)\end{array}$ & $\begin{array}{l}12.319 \text { *** } \\
(2.70)\end{array}$ \\
\hline $\begin{array}{l}\text { Chi-squared value } \\
\text { (overidentification) } \\
\text { P-value (Durbin-Wu- } \\
\text { Hausman exogeneity) }\end{array}$ & \multicolumn{2}{|c|}{0.2530} & \multicolumn{2}{|c|}{20.8227} & \multicolumn{2}{|c|}{1.7348} \\
\hline R-squared & 0.11 & - & 0.12 & - & 0.13 & - \\
\hline Sample size & 28,696 & 28,696 & 13,996 & 13,996 & 14,700 & 14,700 \\
\hline
\end{tabular}

Note: All regressions include state and year dummies. All regressions employ NHANES sample weights. Absolute values of t-ratios are reported in parentheses. Robust standard errors on which they are based allow for state clustering.

*Significant at the $10 \%$ level, **Significant at the 5\% level, ***Significant at the $1 \%$ level. 
Table 3

Body Mass Index Regressions, By Race, Persons 17 Years of Age and Older

\begin{tabular}{|c|c|c|c|c|c|c|}
\hline \multirow[t]{2}{*}{ Independent Variables } & \multicolumn{2}{|c|}{ White Non-Hispanic } & \multicolumn{2}{|c|}{ Black Non-Hispanic } & \multicolumn{2}{|c|}{ Hispanic } \\
\hline & (1) OLS & (2) TSLS & (1) OLS & (2) TSLS & (1) OLS & (2) TSLS \\
\hline Activity-adjusted & $0.0003 * * *$ & 0.002 & $0.001 * * *$ & 0.012 & $0.0004 * * *$ & 0.002 \\
\hline caloric intake & $(3.35)$ & $(1.25)$ & $(4.62)$ & $(1.45)$ & $(3.53)$ & (1.09) \\
\hline Smoking & $\begin{array}{l}-1.280 * * * \\
(14.07)\end{array}$ & $\begin{array}{l}-3.394 \\
(1.06)\end{array}$ & $\begin{array}{l}-1.746 * * * \\
(7.35)\end{array}$ & $\begin{array}{r}4.237 \\
(0.52)\end{array}$ & $\begin{array}{l}-1.139 * * * \\
(3.17)\end{array}$ & $\begin{array}{l}-5.780 * * * \\
(2.91)\end{array}$ \\
\hline Male & $\begin{array}{l}0.726 * * * \\
(4.37)\end{array}$ & $\begin{array}{l}-0.294 \\
(0.26)\end{array}$ & $\begin{array}{l}-2.127 * * * \\
(11.27)\end{array}$ & $\begin{array}{l}-8.256^{*} \\
(1.80)\end{array}$ & $\begin{array}{l}-0.541^{*} \\
(1.78)\end{array}$ & $\begin{array}{l}-0.630 \\
(0.72)\end{array}$ \\
\hline Elementary & $\begin{array}{c}0.228 \\
(1.01)\end{array}$ & $\begin{array}{c}0.218 \\
(0.62)\end{array}$ & $\begin{array}{c}0.082 \\
(0.15)\end{array}$ & $\begin{array}{l}-1.847 \\
(0.94)\end{array}$ & $\begin{array}{l}-0.962 * * * \\
(3.20)\end{array}$ & $\begin{array}{l}-0.799 * * \\
(2.10)\end{array}$ \\
\hline Some high school & $\begin{array}{l}0.248 \\
(1.41)\end{array}$ & $\begin{array}{r}0.222 \\
(0.70)\end{array}$ & $\begin{array}{c}0.036 \\
(0.07)\end{array}$ & $\begin{array}{l}-1.484 \\
(1.02)\end{array}$ & $\begin{array}{l}0.086 \\
(0.47)\end{array}$ & $\begin{array}{l}0.341 \\
(1.16)\end{array}$ \\
\hline High school graduate & $\begin{array}{l}0.119 \\
(0.65)\end{array}$ & $\begin{array}{l}-0.111 \\
(0.35)\end{array}$ & $\begin{array}{l}-0.560 \\
(1.18)\end{array}$ & $\begin{array}{l}-2.094 \\
(1.59)\end{array}$ & $\begin{array}{l}-0.225 \\
(0.62)\end{array}$ & $\begin{array}{l}-0.397 \\
(0.72)\end{array}$ \\
\hline Some college & $\begin{array}{l}-0.384^{*} \\
(1.79)\end{array}$ & $\begin{array}{l}-0.792^{*} \\
(1.90)\end{array}$ & $\begin{array}{l}-0.787 \\
(1.46)\end{array}$ & $\begin{array}{l}-1.972 \\
(1.50)\end{array}$ & $\begin{array}{l}-0.914 * * * \\
(3.81)\end{array}$ & $\begin{array}{l}-1.227 * * \\
(2.60)\end{array}$ \\
\hline College graduate & $\begin{array}{l}-1.180 * * * \\
(5.25)\end{array}$ & $\begin{array}{l}-1.688 * * * \\
(2.71)\end{array}$ & $\begin{array}{l}-1.151 * * \\
(2.52)\end{array}$ & $\begin{array}{l}-1.335 \\
(1.22)\end{array}$ & $\begin{array}{l}-2.002 * * * \\
(4.76)\end{array}$ & $\begin{array}{l}-2.387 * * * \\
(3.73)\end{array}$ \\
\hline Married & $\begin{array}{l}0.442 * \\
(1.93)\end{array}$ & $\begin{array}{l}0.620 * * * \\
(3.03)\end{array}$ & $\begin{array}{l}0.557 \\
(1.66)\end{array}$ & $\begin{array}{l}0.110 \\
(0.27)\end{array}$ & $\begin{array}{l}0.507^{*} \\
(1.71)\end{array}$ & $\begin{array}{l}0.680 * * \\
(2.14)\end{array}$ \\
\hline Divorced & $\begin{array}{l}-0.034 \\
(0.14)\end{array}$ & $\begin{array}{l}0.310 \\
(0.75)\end{array}$ & $\begin{array}{l}-0.615 \\
(1.60)\end{array}$ & $\begin{array}{l}-1.651 \\
(1.31)\end{array}$ & $\begin{array}{l}1.040^{* * *} \\
(2.97)\end{array}$ & $\begin{array}{l}1.644 * * * \\
(5.14)\end{array}$ \\
\hline Widowed & $\begin{array}{l}0.547^{*} \\
(1.78)\end{array}$ & $\begin{array}{l}0.741^{*} \\
(1.89)\end{array}$ & $\begin{array}{l}0.920 * * \\
(2.25)\end{array}$ & $\begin{array}{l}-0.796 \\
(0.49)\end{array}$ & $\begin{array}{l}1.345^{* *} \\
(2.05)\end{array}$ & $\begin{array}{l}2.409 * * \\
(2.41)\end{array}$ \\
\hline Household income & $\begin{array}{l}-0.256^{* * * *} \\
(3.20)\end{array}$ & $\begin{array}{l}-0.353 * * \\
(2.58)\end{array}$ & $\begin{array}{l}0.020 \\
(0.11)\end{array}$ & $\begin{array}{l}0.313 \\
(0.69)\end{array}$ & $\begin{array}{l}0.060 \\
(0.24)\end{array}$ & $\begin{array}{l}-0.170 \\
(0.67)\end{array}$ \\
\hline $\begin{array}{l}\text { Household income } \\
\text { squared }\end{array}$ & $\begin{array}{l}0.018 * * \\
(2.25)\end{array}$ & $\begin{array}{l}0.027 * * \\
(2.21)\end{array}$ & $\begin{array}{l}-0.006 \\
(0.28)\end{array}$ & $\begin{array}{l}-0.011 \\
(0.26)\end{array}$ & $\begin{array}{c}0.002 \\
(0.05)\end{array}$ & $\begin{array}{r}0.027 \\
(0.88)\end{array}$ \\
\hline Age & $\begin{array}{l}0.339 * * * \\
(15.23)\end{array}$ & $\begin{array}{l}0.370^{* * * *} \\
(7.79)\end{array}$ & $\begin{array}{l}0.473^{* * * *} \\
(12.55)\end{array}$ & $\begin{array}{l}0.356^{*} \\
(1.78)\end{array}$ & $\begin{array}{l}0.408^{* * * *} \\
(11.78)\end{array}$ & $\begin{array}{l}0.453^{\text {*** }} \\
(9.88)\end{array}$ \\
\hline Age squared & $\begin{array}{l}-0.003 * * * \\
(13.87)\end{array}$ & $\begin{array}{l}-0.003 * * * \\
(4.76)\end{array}$ & $\begin{array}{l}-0.005^{* * * *} \\
(10.70)\end{array}$ & $\begin{array}{l}-0.002 \\
(0.60) \\
\end{array}$ & $\begin{array}{l}-0.004 * * * \\
(10.17)\end{array}$ & $\begin{array}{l}-0.004^{* * * *} \\
(11.25)\end{array}$ \\
\hline
\end{tabular}


Table 3 (continued)

Body Mass Index Regressions, By Race, Persons 17 Years of Age and Older

\begin{tabular}{|c|c|c|c|c|c|c|}
\hline \multirow[t]{2}{*}{ Independent Variables } & \multicolumn{2}{|c|}{ White Non-Hispanic } & \multicolumn{2}{|c|}{ Black Non-Hispanic } & \multicolumn{2}{|c|}{ Hispanic } \\
\hline & (1) OLS & (2) TSLS & (1) OLS & (2) TSLS & (1) OLS & (2) TSLS \\
\hline Intercept & \begin{tabular}{|l}
$16.533 * * *$ \\
$(32.21)$
\end{tabular} & $\begin{array}{l}14.792 * * * \\
(5.00)\end{array}$ & $\begin{array}{l}17.795^{* * * *} \\
(11.85)\end{array}$ & $\begin{array}{r}2.546 \\
(0.21) \\
\end{array}$ & $\begin{array}{l}18.031 * * * \\
(8.07)\end{array}$ & $\begin{array}{l}22.876^{* * * *} \\
(7.95)\end{array}$ \\
\hline $\begin{array}{l}\begin{array}{l}\text { Chi-squared value } \\
\text { (overidentification) }\end{array} \\
\text { P-value (Durbin-Wu- } \\
\text { Hausman exogeneity) }\end{array}$ & \multicolumn{2}{|c|}{10.0428} & \multicolumn{2}{|c|}{5.5792} & 14. & 5120 \\
\hline R-squared & 0.11 & 0.01 & 0.14 & - & 0.16 & - \\
\hline Instruments & $\begin{array}{c}\text { Activity- } \\
\text { adjusted } \\
\text { caloric intake }\end{array}$ & Smoke & $\begin{array}{c}\text { Activity- } \\
\text { adjusted } \\
\text { caloric intake }\end{array}$ & Smoke & $\begin{array}{c}\text { Activity- } \\
\text { adjusted } \\
\text { caloric intake }\end{array}$ & Smoke \\
\hline $\begin{array}{l}\text { F-values on } \\
\text { instruments }\end{array}$ & 128.51 & 25.90 & 14.59 & 40.49 & 25.75 & 286.94 \\
\hline $\begin{array}{l}\text { Significance of } \\
\text { instruments }\end{array}$ & $\mathrm{p}<0.001$ & $\mathrm{p}<0.001$ & $\mathrm{p}<0.001$ & $\mathrm{p}<0.001$ & $\mathrm{p}<0.001$ & $\mathrm{p}<0.001$ \\
\hline Sample size & 17,881 & 17,881 & 5,837 & 5,837 & 4,580 & 4,580 \\
\hline
\end{tabular}

Note: All regressions include state and year dummies. All regressions employ NHANES sample weights. Absolute values of t-ratios are reported in parentheses. Robust standard errors on which they are based allow for state clustering.

*Significant at the $10 \%$ level, **Significant at the 5\% level, ***Significant at the $1 \%$ level. 


\section{Table 4}

First-Stage Regressions, Whole Sample and By Gender, Persons 17 Years of Age and Older

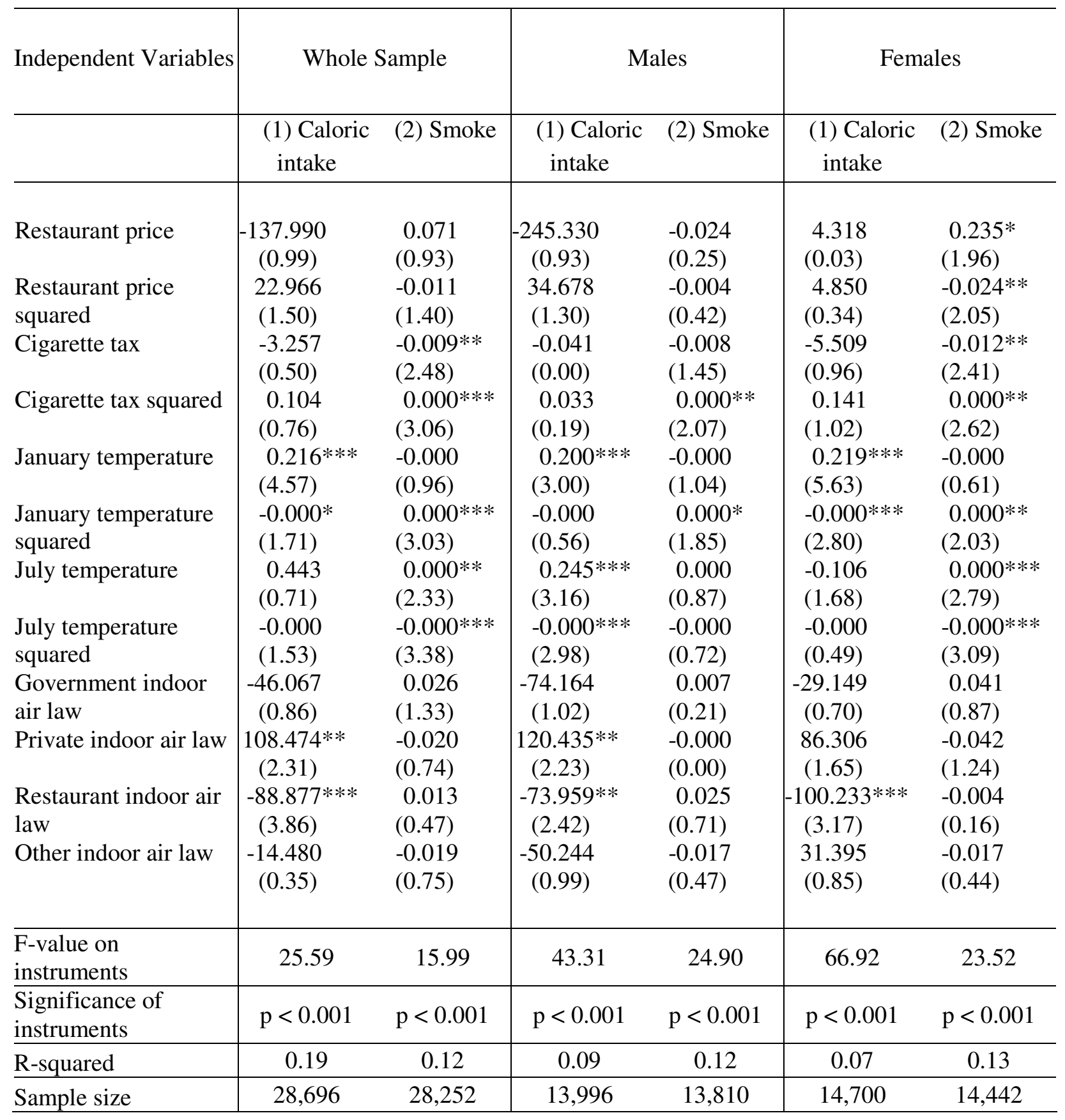

Note: All regressions include state and year dummies, as well as controls for race/ethnicity, age, gender, education, and household income. All regressions employ NHANES sample weights. Absolute values of t-ratios are reported in parentheses. Robust standard errors on which they are based allow for state clustering.

*Significant at the $10 \%$ level, **Significant at the $5 \%$ level, ***Significant at the $1 \%$ level. 


\section{Table 5}

Body Mass Index and the Percentage Obese,

Persons 17 Years of Age and Older, By Activity Intensity in Various Activities in NHANES III

\begin{tabular}{lccc}
\hline $\begin{array}{l}\text { Activity Intensity } \\
\text { (measured as the ratio of } \\
\text { metabolic rate when } \\
\text { engaged in the activity to } \\
\text { resting metabolic rate) }\end{array}$ & Percent of Sample & Body Mass Index & Percentage Obese \\
\hline No intensity & 23.22 & 27.44 & 28.46 \\
$0.1 \sim 49.9$ & 28.02 & 26.99 & 25.81 \\
$50 \sim 99.9$ & 12.11 & 26.12 & 20.03 \\
$100 \sim 149.9$ & 11.56 & 25.82 & 18.85 \\
$150 \sim 199.9$ & 9.16 & 25.74 & 15.25 \\
$200 \sim 299.9$ & 7.78 & 25.68 & 16.73 \\
Greater than 300 & 8.14 & 25.04 & 14.42 \\
\end{tabular}

Survey weights are employed in all computations. 